\title{
Neuronal Activity-Dependent Regulation of MicroRNAs
}

\author{
Su-Eon $\mathrm{Sim}^{1}$, Joseph Bakes ${ }^{1}$, and Bong-Kiun Kaang ${ }^{1,2, *}$
}

\begin{abstract}
MicroRNAs are non-coding short ( 23 nucleotides) RNAs that mediate post-transcriptional regulation through sequence-specific gene silencing. The role of miRNAs in neuronal development, synapse formation and synaptic plasticity has been highlighted. However, the role of neuronal activity on miRNA regulation has been less focused. Neuronal activity-dependent regulation of miRNA may finetune gene expression in response to synaptic plasticity and memory formation. Here, we provide an overview of miRNA regulation by neuronal activity including highthroughput screening studies. We also discuss the possible molecular mechanisms of activity-dependent induction and turnover of miRNAs.
\end{abstract}

\section{INTRODUCTION}

Neuronal activity induces various cellular and molecular changes, which results in the alteration of synaptic strength. In particular, at the synapse level, each synapse shows dynamic responses to specific neuronal activity within a few minutes, which implies that fast and precise molecular machineries are indispensable (Lee et al., 2009; Matsuzaki et al., 2004; Padamsey and Emptage, 2011).

Recent studies revealed a novel post-transcriptional regulatory system using small non-coding RNAs, so-called microRNAs (miRNA), which inhibit protein synthesis by imperfect complementary binding to $3^{\prime}$ untranslated region ( $3^{\prime} \cup T R$ ) of target mRNAs. Transcription of miRNAs produces long primary miRNAs (pri-miRNAs), and then these are processed by Drosha to precursor miRNAs (pre-miRNAs) which form a single hairpin structure. These pre-miRNAs are exported to the cytoplasm by Exportin 5 and further processed by Dicer to 23 -nucleotidelong mature miRNAs. Mature miRNAs are loaded into the RNA-induced silencing complex (RISC) and bind to $3^{\prime}$ UTR of

${ }^{1}$ Department of Brain and Cognitive Sciences, ${ }^{2}$ Department of Biological Sciences, College of Natural Sciences, Seoul National University, Seoul 151-747, Korea

*Correspondence: kaang@snu.ac.kr

Received 19 May, 2014; revised 25 May, 2014; accepted 26 May, 2014; published online 24 June, 2014

Keywords: high-throughput screening, miRNA induction, miRNA turnover, neuronal activity, NMDAR target mRNAs, which results in translational repression and/or mRNA destabilization (Bartel, 2004; Im and Kenny, 2012; Xiong et al., 2013). Translational repression of mRNA driven by miRNAs is an attractive regulatory system for explaining rapid local protein synthesis in response to neuronal activity (Huber et al., 2000; Martin et al., 1997; Sutton and Schuman, 2006). The evidence from many studies showing some miRNAs are specifically enriched in dendrites and synaptosomes also implies the role of miRNAs in neuronal activity (Kye et al., 2007; Lugli et al., 2008; Schratt et al., 2006; Siegel et al., 2009).

In this review, we summarize recent studies reporting activitydependent regulation of miRNAs and discuss how miRNAs are regulated by various types of neuronal activity.

\section{REGULATION OF miRNAs BY NEURONAL ACTIVITY}

Numerous studies have shown that miRNAs are critically regulated by neuronal activity. We summarized a decade of research showing direct regulation of miRNAs in response to various types of neuronal activity (Table 1).

\section{miR-132}

The first and most studied miRNA induced by neuronal activity is miR-132. Many studies have shown a consistent increase of miR-132 after various types of neuronal activity such as brainderived neurotrophic factor (BDNF), $\mathrm{KCl}$ (membrane depolarization) and bicuculline (GABAR Receptor inhibition) in cultured neurons (Chai et al., 2013; Klein et al., 2007; Vo et al., 2005; Wayman et al., 2008) and seizure, contextual fear conditioning, odorant stimulus, light, cocaine intake and visual stimulus in particular brain regions of living animals (Cheng et al., 2007; Im et al., 2010; Nudelman et al., 2010; Tognini et al., 2011). Moreover, reduced neuronal activity such as monocular deprivation in visual cortex decreases both pre- and mature miR-132, strengthening the evidence for neuronal activity-dependent miR-132 induction (Mellios et al., 2011; Tognini et al., 2011). The induction of miR-132 is regulated by cAMP response element binding protein (CREB) which is a crucial stimulus-induced transcription factor regulating many fast-response genes and playing a key role in dendritic development and synaptic plasticity. Studies using pharmacological inhibitors showed that the induction of miR-132 requires activation of NMDA receptor, CaM kinase and MEK-ERK pathways (Cheng et al., 2007; Wayman et al., 2008). 
Neuronal Activity-Dependent Regulation of MicroRNAs

Su-Eon Sim et al.

Table 1. Neuronal activity-dependent regulation of microRNAs

\begin{tabular}{|c|c|c|c|c|c|c|}
\hline \multirow[t]{2}{*}{ miRNA } & \multirow[t]{2}{*}{ Neuronal sources } & \multirow{2}{*}{$\begin{array}{l}\text { Stimuli to induce neuronal } \\
\text { activity }\end{array}$} & \multicolumn{3}{|c|}{ Regulation of miRNAs } & \multirow[t]{2}{*}{ References } \\
\hline & & & Primary & Precursor & Mature & \\
\hline let-7d & $\begin{array}{l}\text { Ventral tegmental area } \\
\text { Hippocampus } \\
\text { Prefrontal cortex }\end{array}$ & Cocaine & & & 1 & $\begin{array}{l}\text { Chandrasekar and } \\
\text { Dreyer (2009) }\end{array}$ \\
\hline$\underline{\operatorname{miR}}-96$ & Retina & Dark adaptation & & 2 & 1 & Krol et al. (2010) \\
\hline \multirow[t]{3}{*}{ miR-124 } & Aplysia neurons & Serotonin & & & $\mathbb{1}$ & $\begin{array}{l}\text { Rajasethupathy et al. } \\
(2009)\end{array}$ \\
\hline & Caudate putamen & \multirow[b]{2}{*}{ Cocaine } & & T & & \multirow[b]{2}{*}{$\begin{array}{l}\text { Chandrasekar and } \\
\text { Dreyer (2009) }\end{array}$} \\
\hline & $\begin{array}{l}\text { Ventral tegmental area } \\
\text { Hippocampus }\end{array}$ & & & & 1 & \\
\hline miR-128b & Infralimbic prefrontal cortex & Fear extinction learning & & & 1 & Lin et al. (2011) \\
\hline \multirow[t]{14}{*}{ miR-132 } & Cortical neuron culture & BDNF & & $\widehat{1}$ & $\boldsymbol{1}$ & Vo et al. (2005) \\
\hline & Cortical neuron culture & Forskolin & & 1 & & Klein et al. (2007) \\
\hline & Suprachiasmatic nuclei & Light & & $\widehat{1}$ & 1 & Cheng et al. (2007) \\
\hline & \multirow{2}{*}{ Hippocampal neuron culture } & Bicuculline & & $\widehat{1}$ & $\widehat{1}$ & \multirow{2}{*}{ Wayman et al. (2008) } \\
\hline & & $\mathrm{KCl}$ & & $\widehat{\top}$ & & \\
\hline & \multirow{3}{*}{ Hippocampus } & $\begin{array}{l}\text { Seizure -muscarinic receptor } \\
\text { agonist }\end{array}$ & $\boldsymbol{1}$ & & & \multirow{4}{*}{ Nudelman et al. (2010) } \\
\hline & & Cocaine & 1 & & & \\
\hline & & Contextual fear conditioning & $\widehat{1}$ & & & \\
\hline & Olfactory bulb & Odorant exposure & $\widehat{1}$ & & & \\
\hline & Dorsal striatum & Cocaine & & & 1 & Im et al. (2010) \\
\hline & Primary visual cortex & $\begin{array}{l}\text { Dark rearing or monocular } \\
\text { deprivation }\end{array}$ & $\boldsymbol{I}$ & & 1 & Mellios et al. (2011) \\
\hline & \multirow{2}{*}{ Visual cortex } & Visual stimulus & $\widehat{1}$ & & $\widehat{1}$ & \multirow{2}{*}{ Tognini et al. (2011) } \\
\hline & & Monocular deprivation & 2 & & 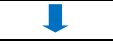 & \\
\hline & Cortical neuron culture & BDNF & & $\boldsymbol{\square}$ & & Chai et al. (2013) \\
\hline \multirow[t]{6}{*}{ miR-134 } & Cortical neuron culture & BDNF & $\begin{array}{l}\text { Inactivatir } \\
\text { silencing }\end{array}$ & $\begin{array}{l}\text { miR-134-a } \\
\text { omplex }\end{array}$ & sociated & Schratt et al. (2006) \\
\hline & \multirow{2}{*}{ Cortical neuron culture } & BDNF & & $\widehat{1}$ & & \multirow{2}{*}{ Fiore et al. (2009) } \\
\hline & & $\mathrm{KCl}$ & & $\boldsymbol{1}$ & & \\
\hline & \multirow{2}{*}{ Infralimbic prefrontal cortex } & Auditory fear conditioning & & & $\widehat{1}$ & \multirow{2}{*}{ Lin et al. (2011) } \\
\hline & & Fear extinction learning & & & $\widehat{1}$ & \\
\hline & Cortical neuron culture & Bicuculline & $\begin{array}{l}\text { Increase } \\
\text { some inte }\end{array}$ & $\begin{array}{l}\text { mature } \mathrm{miF} \\
\text { neurons }\end{array}$ & -134 in & Chai et al. (2013) \\
\hline miR-146a-5p & Hippocampal neuron culture & DHPG & & & E & Chen and Shen (2013) \\
\hline miR-181a & $\begin{array}{l}\text { Nucleus accumbens } \\
\text { Hippocampus }\end{array}$ & Cocaine & & & $\widehat{1}$ & $\begin{array}{l}\text { Chandrasekar and } \\
\text { Dreyer (2009) }\end{array}$ \\
\hline \multirow{2}{*}{ miR-182 } & Retina & Dark adaptation & & T & 2 & Krol et al. (2010) \\
\hline & Lateral amygdala & Auditory fear conditioning & & & T & Griggs et al. (2013) \\
\hline miR-183 & Retina & Dark adaptation & & T & 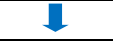 & Krol et al. (2010) \\
\hline miR-184 & Aplysia neurons & Serotonin & & & $\mathbf{I}$ & $\begin{array}{l}\text { Rajasethupathy et al. } \\
(2009)\end{array}$ \\
\hline miR-188 & Hippocampus & Chemical LTP & & & 1 & Lee et al. (2012) \\
\hline miR-204 & Retina & Dark adaptation & & I & 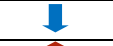 & Krol et al. (2010) \\
\hline miR-206 & Medial prefrontal cortex & Prolonged alcohol exposure & & & $\widehat{1}$ & Tapocik et al. (2014) \\
\hline miR-211 & Retina & Dark adaptation & & T & 2 & Krol et al. (2010) \\
\hline \multirow{2}{*}{ miR-212 } & \multirow{2}{*}{ Dorsal striatum } & \multirow{2}{*}{ Cocaine } & & & 1 & Hollander et al. (2010) \\
\hline & & & & & 1 & Im et al. (2010) \\
\hline miR-219 & Prefrontal cortex & $\begin{array}{l}\text { Acute injection of dizocilpine, } \\
\text { NMDAR antagonist }\end{array}$ & & & $\mathbb{1}$ & Kocerha et al. (2009) \\
\hline & Suprachiasmatic nuclei & $\begin{array}{l}\text { Circadian rhythm, } \\
\text { subjective day }\end{array}$ & & $\boldsymbol{1}$ & $\boldsymbol{1}$ & Cheng et al. (2007) \\
\hline miR-485 & Hippocampal neuron culture & $\begin{array}{l}\text { Bicuculline } \\
\text { 4-aminopyridine (4-AP) }\end{array}$ & & $\boldsymbol{\top}$ & $\boldsymbol{1}$ & Cohen et al. (2011) \\
\hline
\end{tabular}




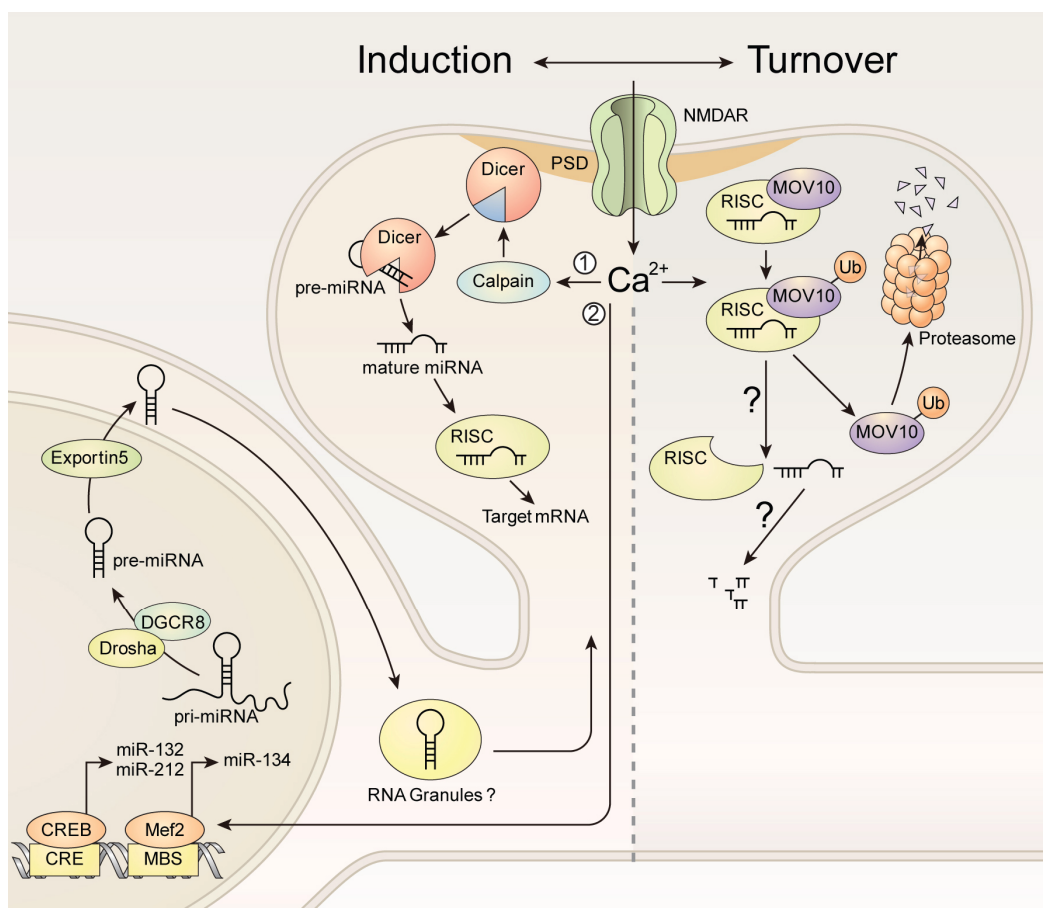

Fig. 1. Possible mechanisms for neuronal activity-dependent miRNA regulation. There are two possible mechanisms for miRNA induction. First, the influx of $\mathrm{Ca}^{2+}$ via NMDAR activates a calcium-dependent enzyme, calpain. Activated calpain is known to release Dicer from PSD and to stimulate Dicer RNAse III activity, which facilitates the process of pre-miRNAs into mature miRNAs. Second, increased intracellular $\mathrm{Ca}^{2+}$ level triggers downstream signaling pathways and induces de novo miRNA transcription. However, little is known about the mechanism of miRNA turnover. One possible mechanism is the activity-dependent degradation of RISC. MOV10, RISC factor, is degraded by proteasome in activity-dependent manner, but is still not clear whether this degradation of MOV10 induces the disassembly of RISC and the turnover of miRNA.

\section{miR-212}

miR-212 is another CREB-dependent miRNA. The locus of miR-212 is located only 200 bases upstream from that of miR132 and the promoter regions of both miR-132 and miR-212 have CRE sequences (Magill et al., 2010; Remenyi et al., 2013; Vo et al., 2005). There are fewer studies about miR-212 compared to miR-132. Kenny and colleagues have studied the role of miR-212 in cocaine addiction related to CREB signaling in dorsal striatum (Hollander et al., 2010; Im et al., 2010). Authors showed that miR-212 is specifically induced by extended but not restricted cocaine access and amplifying CREB signaling via a novel molecular feed-forward circuit.

\section{miR-134}

The regulation of miR-134 is more complicated than other miRNAs. Schratt et al. (2006) showed that synaptodendritically localized miR-134 negatively regulates dendritic spine size by repressing the translation of target Lim-domain-containing protein kinase 1 (LimK1) mRNA. After BDNF treatment, the translation of LimK1 is increased by the relief of miR-134 inhibition, which suggests miR-134-associated silencing complex is inactivated or diminished at the synaptodendritic compartment. On the other hand, Fiore et al. showed that BDNF stimulation increases the level of pre-miR-134 via de novo miR-134 transcription. In their paper, the authors showed that the miR-134 gene is included in a large cluster of miRNAs (more than 50 miRNAs) and polycistronically transcribed by the activityregulated transcription factor, myocyte enhancing factor 2 (Mef2) (Fiore et al., 2009). The results of these two studies imply that miR-134 might be regulated differently in the local synaptodendritic compartment compared to the global transcription level. Moreover, a recent paper suggested a new possibility. It showed activity-dependent response of miR-134 is only restricted to certain types of cortical interneurons, Somatostatin (SST) and Calretinin positive interneurons (Chai et al.,
2013). The authors of this paper compared the induction of miR-134 and miR-132 by BDNF-stimulation in hippocampal culture, and found a relatively small increase of miR-134 compared to that of miR-132. Therefore, they measured cell typespecific responses using a fluorescent miRNA sensor (Magill et al., 2010) and found an activity-dependent response restricted to SST and Calretinin positive interneurons. There are two studies supporting this cell type-specific regulation of miR-134. First, similar results were observed in the study of Bramham and colleagues. When the levels of miR-132, miR-212 and miR-134 were measured $2 \mathrm{~h}$ after in vivo long-term potentiation (LTP) in the dentate gyrus (DG) of the hippocampus, two CREB-regulated miRNAs, miR-132 and miR-212, showed a significant increase but the level of miR-134 was unchanged (Wibrand et al., 2010). More evidence can be found in a fabulous study by Huang and colleagues. Using conditional GFPmyc-Ago2 transgenic mice and various Cre recombinase mice, the authors revealed cell type-specific expression profiles of miRNAs. In their results, the expression of miR-134 is more enriched in parvalbumin (PV), SST and glutamate decarboxylase 2 (GAD2) positive GABAergic interneurons than Calcium/Calmodulin-dependent protein kinase II alpha (CaMKIla) positive glutamatergic pyramidal neuron, whereas miR-132 and miR-212 are predominantly expressed in CaMKIl $\alpha$ positive neurons (He et al., 2012). More research is required to clarify the exact activity-dependent regulation of miR-134.

\section{miR-124}

The brain-enriched and highly conserved miRNA, miR-124, has been studied largely for its role in neuronal development (Cao et al., 2007; Cheng et al., 2009; Landgraf et al., 2007; Makeyev et al., 2007; Yu et al., 2008). Kandel and colleagues first demonstrated the activity-dependent regulation of miR-124 in Aplysia californica. miR-124 showed restricted expression in the sensory neuron compared to the motor neuron. The treatment 
Neuronal Activity-Dependent Regulation of MicroRNAs

Su-Eon Sim et al.

Table 2. Screening studies for activity-regulated miRNAs

\begin{tabular}{|c|c|c|c|c|}
\hline References & Sources & Stimulus & Protocol & $\begin{array}{l}\text { miRNA detection } \\
\text { methods }\end{array}$ \\
\hline \multirow{2}{*}{$\begin{array}{l}\text { Park and Tang } \\
\text { (2009) }\end{array}$} & \multirow{2}{*}{ Hippocampal slices } & Chemical LTP & TEA (25 mM), no $\mathrm{Mg}^{2+}$, high $\mathrm{Ca}^{2+}, 15 \mathrm{~min}$ & \multirow{2}{*}{ Microarray } \\
\hline & & mGluR-LTD & DHPG (100 uM), $15 \mathrm{~min}$ & \\
\hline $\begin{array}{l}\text { Wibrand et al. } \\
\text { (2010) }\end{array}$ & Hippocampal DG & In vivo LTP & $\begin{array}{l}\text { Single session: } 8 \text { pulses at } 400 \mathrm{~Hz} \text {, } \\
\text { repeated four times, } 10 \text { s interval } \\
\text { Apply } 3 \text { sessions with } 5 \text { min interval }\end{array}$ & Microarray \\
\hline \multirow[t]{2}{*}{ Eacker et al. (2011) } & \multirow[b]{2}{*}{ Hippocampus } & \multirow{2}{*}{$\begin{array}{l}\text { Electroconvulsive shock } \\
\text { (synchronous } \\
\text { depolarization) }\end{array}$} & \multirow[b]{2}{*}{$1 \mathrm{~s}, 100 \mathrm{~Hz}, 22 \mathrm{~mA}$ current } & Deep sequencing \\
\hline & & & & $\begin{array}{l}\text { Taqman low- } \\
\text { density array }\end{array}$ \\
\hline \multirow{3}{*}{ Kye et al. (2011) } & Hippocampal CA1 & Contextual conditioning & $2 \mathrm{~s}, 0.75 \mathrm{~mA}, 3$ footshock & \multirow{3}{*}{ qRT-PCR } \\
\hline & \multirow{2}{*}{$\begin{array}{l}\text { DIV15 hippocampal } \\
\text { culture }\end{array}$} & \multirow{2}{*}{ Chemical stimulation } & NMDA (60 uM), $5 \mathrm{~min}$ & \\
\hline & & & Bicuculline (20 uM), $1 \mathrm{~h}$ & \\
\hline \multirow[t]{2}{*}{ Mellios et al. (2011) } & \multirow{2}{*}{$\begin{array}{l}\text { Primary visual } \\
\text { cortex }\end{array}$} & Visual deprivation & Reared with eyelid sutured from P24-28 & \multirow{2}{*}{$\begin{array}{l}\text { Microarray } \\
\text { qRT-PCR }\end{array}$} \\
\hline & & Dark rearing & Reared in darkness from birth & \\
\hline \multirow{4}{*}{$\begin{array}{l}\text { van Spronse et al. } \\
(2013)\end{array}$} & \multirow{4}{*}{$\begin{array}{l}\text { DIV21 hippocampal } \\
\text { culture }\end{array}$} & Chemical LTP & Glycine (200 uM), 5 min & \multirow{4}{*}{ Microarray } \\
\hline & & Chemical LTD & NMDA (50 uM), 5 min & \\
\hline & & $\begin{array}{l}\text { Prolonged decrease of } \\
\text { synaptic activity }\end{array}$ & TTX (2 uM), $4 \mathrm{~h}$ or $48 \mathrm{~h}$ & \\
\hline & & $\begin{array}{c}\text { Prolonged increase of } \\
\text { synaptic activity }\end{array}$ & Bicuculline (40 uM), $4 \mathrm{~h}$ or $48 \mathrm{~h}$ & \\
\hline Pai et al. (2014) & Hippocampal DG & In vivo LTP & $\begin{array}{l}\text { Single Session: } 8 \text { pulses at } 400 \mathrm{~Hz} \text {, } \\
\text { repeated four times, } 10 \mathrm{~s} \text { interval } \\
\text { Apply } 3 \text { sessions with } 5 \text { min interval }\end{array}$ & $\begin{array}{l}\text { Ago2 immunopre- } \\
\text { cipitation } \\
\text { Microarray }\end{array}$ \\
\hline
\end{tabular}

of five spaced pulses of 5-hydroxytryptamine (5-HT) which induces long-term facilitation (LTF) at the sensory-to-motor synapse decreased the level of mature miR-124, whereas the treatment of one pulse of $5-\mathrm{HT}$ did not show any change. The decrease of miR-124 is dependent on the MAPK signaling pathway but not on PKA, PKC and the proteasome pathways (Rajasethupathy et al., 2009). The decrease of miR-124 by neuronal activity was also observed in the mammalian nervous system. Chronic cocaine administration induced a significant decrease of precursor miR-124 in the caudate putamen and decrease of mature miR-124 in the hippocampus, in the nucleus accumbens and in the caudate putamen. The significant up-regulation of repressor element 1 silencing transcription factor (REST), a transcriptional repressor which inhibits the expression of miR-124 (Conaco et al., 2006), in the nucleus accumbens and in the caudate putamen suggests the decrease of miR-124 is mediated by the regulation of REST (Chandrasekar and Dreyer, 2009).

\section{Retinal miRNAs}

The study of Krol et al. (2010) provides clear evidence of dynamic regulation of miRNAs by a stimulus. Several retinal miRNAs, miR-183/96/182 cluster, miR-204 and miR-211, were dynamically up- and down-regulated by light. The levels of these miRNAs were remarkably decreased by dark adaptation and rapidly recover to their maximum levels within 30 min after return to light.

\section{HIGH-THROUGHPUT SCREENING STUDIES}

There are several screening studies looking for global changes of miRNAs after neuronal activities (Table 2).

Chemical stimulation in hippocampal slices

The study of Park and Tang examined a time-dependent change in miRNAs after chemical LTP (c-LTP) or metabotropic glutamate receptor-dependent long-term depression (mGluRLTD) in hippocampal slices. Among 237 miRNAs tested by microarray, 50 miRNAs and 59 miRNAs were increased more than 8 folds after C-LTP and mGluR-LTD stimulation, respectively. Interestingly, most of the miRNAs were increased within $15 \mathrm{~min}$ after c-LTP and $30 \mathrm{~min}$ after mGluR-LTD (Park and Tang, 2009).

In vivo electrical stimulation

The rapid induction of miRNAs was also observed in living animals. Electroconvulsive shock was given to induce massive and synchronous depolarization of hippocampal neurons. Expression levels of miRNAs measured by Taqman low-density array showed that most miRNAs were increased rapidly within $1 \mathrm{~h}$ (Eacker et al., 2011).

Bramham and colleagues performed microarray analysis using the high frequency stimulus (HFS) paradigm for in vivo LTP in DG of urethane-anesthetized rats. Tested time points were $10 \mathrm{~min}$ and $2 \mathrm{~h}$ after HFS, and only $2 \mathrm{~h}$ after-HFS showed significant miRNA expression changes. The expression levels of 10 miRNAs were increased and 11 miRNAs were decreased among 237 tested miRNAs (Wibrand et al., 2010). Compared to a previous study (Park and Tang, 2009), fewer miRNAs were induced at the delayed time point and even some miRNAs were decreased. We believe these milder changes were caused by different stimulus protocols. The HFS stimulation 
used in this paper is considered closer to physiological conditions compared to the chemical stimulus used in the previous study.

\section{Chemical stimulation in neuron cultures}

The study of van Spronsen et al. (2013) examined the activitydependent change in miRNA using mature primary hippocampal neuron cultures. The authors investigated the change in 264 miRNAs after NMDA receptor-mediated synaptic plasticity or homeostatic synaptic plasticity using microarray analysis. A chemical LTP or a chemical long-term depression (LTD) protocol was used for NMDA receptor-mediated synaptic plasticity, which induced a change in expression of 51 miRNAs. For homeostatic synaptic plasticity, either voltage-gated sodium channel blocker tetrodotoxin (TTX, suppress action potential) or GABAA receptor antagonist bicuculline (increase synaptic activity) was treated for $4 \mathrm{~h}$ or $48 \mathrm{~h}$. Prolonged change of synaptic activity in neuron culture altered the expression of 31 miRNAs.

\section{Behavioral stimulation and pathogenic condition}

Specific experiences may induce the changes in miRNA expression. Kye et al. (2011) studied the change in miRNAs in the hippocampus after contextual fear conditioning. The expression of 187 miRNAs in the hippocampal CA1 region was measured by quantitative real time PCR (qRT-PCR) at three different time points after training ( $1 \mathrm{~h}, 3 \mathrm{~h}$, and $24 \mathrm{~h}$ ). Astonishingly, a single training session significantly changed the expression level of almost half of measured miRNAs (90 miRNAs). Sur and colleagues screened miRNAs in the primary visual cortex (V1) responding to visual deprivation via microarray analysis. Among the top 100 most highly expressed miRNAs in V1, the expression level of 21 miRNAs was altered by visual deprivation. The authors verified the altered 21 miRNAs using qRTPCR, and confirmed that the expression of 9 miRNAs was changed (Mellios et al., 2011).

Interestingly, there is a report showing that miRNA dysregulation is linked to the pathogenesis of neurodegenerative diseases such as Amyotrophic Lateral Sclerosis (ALS) (CamposMelo et al., 2013). This study analyzed the expression profile of 664 miRNAs in the sporadic ALS spinal cord tissues. The results showed that there is a specific group of dysregulated miRNAs and that specific miRNA dysregulation might be related to the selective suppression of neurofilament miRNA observed in sporadic ALS.

\section{MECHANISM OF ACTIVITY-DEPENDENT MIRNA REGULATION}

\section{Mechanism for induction}

There are two possible mechanisms for the induction of miRNA (Fig. 1). The first mechanism is suggested by the finding which showed neuronal activity induces the cleavage of Dicer and increases its RNAse III activity. This study showed that enzymatically inactive Dicer is enriched at postsynaptic densities (PSD), and is released and activated by calcium-dependent calpain activation (Lugli et al., 2005). Because Dicer is a key enzyme to produce mature miRNAs, the release of active Dicer might process most of the pre-miRNAs located in dendritic spine all at once. This mechanism may explain the results of previous studies reporting fast induction of many miRNAs after stimulation (Eacker et al., 2011; Park and Tang, 2009). The second miRNA induction mechanism is de novo transcription of miRNAs by activity-regulated transcription factors such as CREB and Mef2. As mentioned above, many studies have shown CREB-dependent induction of miR-132 and miR-212 (Nudelman et al., 2010; Remenyi et al., 2013; Vo et al., 2005; Wayman et al., 2008) and one study proved Mef2 binds upstream of the miR-379-410 cluster, which includes the miR-134 gene, and transcribes the gene in an activity-dependent manner (Fiore et al., 2009). There is still another mechanism for regulating miR-134 transcription. Tsai and colleagues found that the mammalian Sir2 homolog, SIRT1, forms a repressor complex with transcription factor, Yin Yang 1 (YY1), and binds upstream of miR-134 to inhibit its expression (Gao et al., 2010). Even though this paper did not demonstrate a direct induction of miR-134 after neural activation, other evidence clearly suggests transcriptional regulation of miR-134 via SIRT1 and YY1.

\section{Mechanism for turnover}

Compared to induction of miRNA, little is known of the activitydependent neuronal miRNA turnover. This lack of attention might be related to previous studies which have shown that miRNAs are highly stable and have slow turnover rates (Bhattacharyya et al., 2006; Gantier et al., 2011; van Rooij et al., 2007). Meanwhile, Krol et al. (2010) provide a new insight into the nature of miRNA turnover, reporting that miRNAs in neuron have rapid turnover rates that are dependent on neuronal activity. The level of miRNAs in mouse retina was rapidly, within a few hours, decreased after transcriptional shut-down via transcription inhibitors. This fast turnover of neuronal miRNA was also observed in non-retinal neurons, such as organotypic hippocampal slices, hippocampal and cortical culture neurons and even neurons derived from mouse embryonic stem cells. Furthermore, the authors showed that the treatment of TTX blocks rapid turnover of miRNAs, which implies that the high turnover rate of neuronal miRNAs is dependent on neuronal activity.

Until now, almost nothing is known about the mechanism for neuronal activity-dependent miRNA turnover. One possible mechanism is the degradation of RISC by neuronal activity (Fig 1). In Drosophila, Armitage, one of the RISC factors, is rapidly degraded after neuronal activity (Ashraf et al., 2006). Kosik and colleagues also observed the activity-dependent degradation of MOV10, a mammalian ortholog of Armitage (Banerjee et al., 2009). Both Armitage and MOV10 are degraded by the proteasome.

\section{CONCLUSION}

Synaptic activity across neurons is the most fundamental feature of neurons. We focused here on how neuronal activity regulates the level of miRNAs. From a decade of efforts, a good body of evidence has elucidated the mechanism of miRNA regulation. Particularly, high-throughput studies provide new insights for understanding global changes in miRNAs.

In the future, more studies about cell type-specific or neuronal circuit-specific miRNA regulation are demanded to understand the diversity and complexity of brain function.

\section{ACKNOWLEDGMENTS}

This study was supported by the National Honor Scientist Program of Korea.

\section{REFERENCES}

Ashraf, S.I., McLoon, A.L., Sclarsic, S.M., and Kunes, S. (2006). Synaptic protein synthesis associated with memory is regulated by the RISC pathway in Drosophila. Cell 124, 191-205.

Banerjee, S., Neveu, P., and Kosik, K.S. (2009). A coordinated local translational control point at the synapse involving relief from si- 
lencing and MOV10 degradation. Neuron 64, 871-884.

Bartel, D.P. (2004). MicroRNAs: genomics, biogenesis, mechanism, and function. Cell 116, 281-297.

Bhattacharyya, S.N., Habermacher, R., Martine, U., Closs, E.I., and Filipowicz, W. (2006). Relief of microRNA-mediated translational repression in human cells subjected to stress. Cell 125,1111 1124.

Campos-Melo, D., Droppelmann, C.A., He, Z., Volkening, K., and Strong, M.J. (2013). Altered microRNA expression profile in amyotrophic lateral sclerosis: a role in the regulation of NFL mRNA levels. Mol. Brain 6, 26.

Cao, X., Pfaff, S.L., and Gage, F.H. (2007). A functional study of miR-124 in the developing neural tube. Genes Dev. 21, 531-536.

Chai, S., Cambronne, X.A., Eichhorn, S.W., and Goodman, R.H. (2013). MicroRNA-134 activity in somatostatin interneurons regulates $\mathrm{H}$-Ras localization by repressing the palmitoylation enzyme, DHHC9. Proc. Natl. Acad. Sci. USA 110, 17898-17903.

Chandrasekar, V., and Dreyer, J.-L. (2009). microRNAs miR-124, let-7d and miR-181a regulate cocaine-induced plasticity. Mol. Cell. Neurosci. 42, 350-362.

Chen, Y.-L., and Shen, C.-K.J. (2013). Modulation of mGluRdependent MAP1B translation and AMPA receptor endocytosis by microRNA miR-146a-5p. J. Neurosci. 33, 9013-9020.

Cheng, H.-Y.M., Papp, J.W., Varlamova, O, Dziema, H., Russell, B., Curfman, J.P., Nakazawa, T., Shimizu, K., Okamura, H., and Impey, S. (2007). microRNA modulation of circadian-clock period and entrainment. Neuron 54, 813-829.

Cheng, L.-C., Pastrana, E., Tavazoie, M., and Doetsch, F. (2009). miR-124 regulates adult neurogenesis in the subventricular zone stem cell niche. Nat. Neurosci. 12, 399-408.

Cohen, J.E., Lee, P.R., Chen, S., Li, W., and Fields, R.D. (2011). MicroRNA regulation of homeostatic synaptic plasticity. Proc. Natl. Acad. Sci. USA 108, 11650-11655.

Conaco, C., Otto, S., Han, J.-J., and Mandel, G. (2006). Reciprocal actions of REST and a microRNA promote neuronal identity. Proc. Natl. Acad. Sci. USA 103, 2422-2427.

Eacker, S.M., Keuss, M.J., Berezikov, E., Dawson, V.L., and Dawson, T.M. (2011). Neuronal activity regulates hippocampal miRNA expression. PLoS One 6, e25068.

Fiore, R., Khudayberdiev, S., Christensen, M., Siegel, G., Flavell, S.W., Kim, T.K., Greenberg, M.E., and Schratt, G. (2009). Mef2-mediated transcription of the miR379-410 cluster regulates activity-dependent dendritogenesis by fine-tuning Pumilio2 protein levels. EMBO J. 28, 697-710.

Gantier, M.P., McCoy, C.E., Rusinova, I., Saulep, D., Wang, D., Xu, D., Irving, A.T., Behlke, M.A., Hertzog, P.J., and Mackay, F. (2011). Analysis of microRNA turnover in mammalian cells following Dicer1 ablation. Nucleic Acids Res. 39, 5692-5703.

Gao, J., Wang, W.-Y., Mao, Y.-W., Gräff, J., Guan, J.-S., Pan, L., Mak, G., Kim, D., Su, S.C., and Tsai, L.-H. (2010). A novel pathway regulates memory and plasticity via SIRT1 and miR134. Nature 466, 1105-1109.

Griggs, E.M., Young, E.J., Rumbaugh, G., and Miller, C.A. (2013). MicroRNA-182 regulates amygdala-dependent memory formation. J. Neurosci. 33, 1734-1740.

He, M., Liu, Y., Wang, X., Zhang, M.Q., Hannon, G.J., and Huang, Z.J. (2012). Cell-type-based analysis of microRNA profiles in the mouse brain. Neuron $73,35-48$.

Hollander, J.A., Im, H.-I., Amelio, A.L., Kocerha, J., Bali, P., Lu, Q., Willoughby, D., Wahlestedt, C., Conkright, M.D., and Kenny, P.J. (2010). Striatal microRNA controls cocaine intake through CREB signalling. Nature 466, 197-202.

Huber, K.M., Kayser, M.S., and Bear, M.F. (2000). Role for rapid dendritic protein synthesis in hippocampal mGluR-dependent long-term depression. Science 288, 1254-1256.

Im, H.-I., and Kenny, P.J. (2012). MicroRNAs in neuronal function and dysfunction. Trends Neurosci. 35, 325-334.

Im, H.-I., Hollander, J.A., Bali, P., and Kenny, P.J. (2010). MeCP2 controls BDNF expression and cocaine intake through homeostatic interactions with microRNA-212. Nat. Neurosci. 13, 11201127.

Klein, M.E., Lioy, D.T., Ma, L., Impey, S., Mandel, G., and Goodman, R.H. (2007). Homeostatic regulation of MeCP2 expression by a CREB-induced microRNA. Nat. Neurosci. 10, 1513-1514.

Kocerha, J., Faghihi, M.A., Lopez-Toledano, M.A., Huang, J., Ramsey, A.J., Caron, M.G., Sales, N., Willoughby, D., Elmen, J., and
Hansen, H.F. (2009). MicroRNA-219 modulates NMDA receptor-mediated neurobehavioral dysfunction. Proc. Natl. Acad. Sci. USA 106, 3507-3512.

Krol, J., Busskamp, V., Markiewicz, I., Stadler, M.B., Ribi, S., Richter, J., Duebel, J., Bicker, S., Fehling, H.J., and Schübeler, D. (2010). Characterizing light-regulated retinal microRNAs reveals rapid turnover as a common property of neuronal microRNAs. Cell 141, 618-631.

Kye, M.-J., Liu, T., Levy, S.F., Xu, N.L., Groves, B.B., Bonneau, R., Lao, K., and Kosik, K.S. (2007). Somatodendritic microRNAs identified by laser capture and multiplex RT-PCR. RNA 13, 1224-1234.

Kye, M.J., Neveu, P., Lee, Y.-S., Zhou, M., Steen, J.A., Sahin, M. Kosik, K.S., and Silva, A.J. (2011). NMDA mediated contextual conditioning changes miRNA expression. PLoS One 6, e24682.

Landgraf, $P$, Rusu, M. Sheridan, R , Sewer, A., lovino, N., Aravin, A., Pfeffer, S., Rice, A., Kamphorst, A.O., and Landthaler, M (2007). A mammalian microRNA expression atlas based on small RNA library sequencing. Cell 129, 1401-1414.

Lee, S.-J.R., Escobedo-Lozoya, Y., Szatmari, E.M., and Yasuda, R. (2009). Activation of CaMKII in single dendritic spines during long-term potentiation. Nature 458, 299-304.

Lee, K., Kim, J.-H., Kwon, O.-B., An, K., Ryu, J., Cho, K., Suh, Y.-H., and Kim, H.-S. (2012). An activity-regulated microRNA, miR-188, controls dendritic plasticity and synaptic transmission by downregulating neuropilin-2. J. Neurosci. 32, 5678-5687.

Lin, Q., Wei, W., Coelho, C.M., Li, X., Baker-Andresen, D., Dudley, K., Ratnu, V.S., Boskovic, Z., Kobor, M.S., and Sun, Y.E. (2011) The brain-specific microRNA miR-128b regulates the formation of fear-extinction memory. Nat. Neurosci. 14, 1115-1117.

Lugli, G., Larson, J., Martone, M.E., Jones, Y., and Smalheiser, N.R (2005). Dicer and elF2c are enriched at postsynaptic densities in adult mouse brain and are modified by neuronal activity in a calpain-dependent manner. J. Neurochem. 94, 896-905.

Lugli, G., Torvik, V.I., Larson, J., and Smalheiser, N.R. (2008). Expression of microRNAs and their precursors in synaptic fractions of adult mouse forebrain. J. Neurochem. 106, 650-661.

Magill, S.T., Cambronne, X.A., Luikart, B.W., Lioy, D.T., Leighton, B.H., Westbrook, G.L., Mandel, G., and Goodman, R.H. (2010). microRNA-132 regulates dendritic growth and arborization of newborn neurons in the adult hippocampus. Proc. Natl. Acad. Sci. USA 107, 20382-20387.

Makeyev, E.V., Zhang, J., Carrasco, M.A., and Maniatis, T. (2007). The MicroRNA miR-124 promotes neuronal differentiation by triggering brain-specific alternative pre-mRNA splicing. Mol. Cell 27, 435-448.

Martin, K.C., Casadio, A., Zhu, H., Rose, J.C., Chen, M., Bailey, C.H., and Kandel, E.R. (1997). Synapse-specific, long-term facilitation of Aplysia sensory to motor synapses: a function for local protein synthesis in memory storage. Cell 91, 927-938.

Matsuzaki, M., Honkura, N., Ellis-Davies, G.C., and Kasai, H. (2004). Structural basis of long-term potentiation in single dendritic spines. Nature 429, 761-766.

Mellios, N., Sugihara, H., Castro, J., Banerjee, A., Le, C., Kumar, A., Crawford, B., Strathmann, J., Tropea, D., and Levine, S.S (2011). miR-132, an experience-dependent microRNA, is essential for visual cortex plasticity. Nat. Neurosci. 14, 1240-1242.

Nudelman, A.S., DiRocco, D.P., Lambert, T.J., Garelick, M.G., Le, J., Nathanson, N.M., and Storm, D.R. (2010). Neuronal activity rapidly induces transcription of the CREB-regulated microRNA-132, in vivo. Hippocampus 20, 492-498.

Padamsey, Z., and Emptage, N.J. (2011). Imaging synaptic plasticity. Mol. Brain 4, 36.

Pai, B., Siripornmongcolchai, T., Berentsen, B., Pakzad, A., Vieuille, C., Pallesen, S., Pajak, M., Simpson, T.I., Armstrong, J.D., and Wibrand, K. (2014). NMDA receptor-dependent regulation of miRNA expression and association with Argonaute during LTP in vivo. Front. Cell. Neurosci. 7, 285.

Park, C.S., and Tang, S.-J. (2009). Regulation of microRNA expression by induction of bidirectional synaptic plasticity. J. Mol. Neurosci. 38, 50-56.

Rajasethupathy, P., Fiumara, F., Sheridan, R., Betel, D., Puthanveettil, S.V., Russo, J.J., Sander, C., Tuschl, T., and Kandel, E. (2009). Characterization of small RNAs in Aplysia reveals a role for miR-124 in constraining synaptic plasticity through CREB. Neuron 63, 803-817. 
Remenyi, J., van den Bosch, M.W., Palygin, O., Mistry, R.B., McKenzie, C., Macdonald, A., Hutvagner, G., Arthur, J.S.C., Frenguelli, B.G., and Pankratov, Y. (2013). miR-132/212 knockout mice reveal roles for these miRNAs in regulating cortical synaptic transmission and plasticity. PLoS One 8, e62509.

Schratt, G.M., Tuebing, F., Nigh, E.A., Kane, C.G., Sabatini, M.E., Kiebler, M., and Greenberg, M.E. (2006). A brain-specific microRNA regulates dendritic spine development. Nature 439, 283-289.

Siegel, G., Obernosterer, G., Fiore, R., Oehmen, M., Bicker, S., Christensen, M., Khudayberdiev, S., Leuschner, P.F., Busch, C. J., and Kane, C. (2009). A functional screen implicates microRNA-138-dependent regulation of the depalmitoylation enzyme APT1 in dendritic spine morphogenesis. Nat. Cell Biol. 11, 705716.

Sutton, M.A., and Schuman, E.M. (2006). Dendritic protein synthesis, synaptic plasticity, and memory. Cell 127, 49-58.

Tapocik, J.D., Barbier, E., Flanigan, M., Solomon, M., Pincus, A., Pilling, A., Sun, H., Schank, J.R., King, C., and Heilig, M. (2014). microRNA-206 in rat medial prefrontal cortex regulates BDNF expression and alcohol drinking. J. Neurosci. 34, 4581-4588.

Tognini, P., Putignano, E., Coatti, A., and Pizzorusso, T. (2011). Experience-dependent expression of miR-132 regulates ocular dominance plasticity. Nat. Neurosci. 14, 1237-1239.

van Rooij, E., Sutherland, L.B., Qi, X., Richardson, J.A., Hill, J., and Olson, E.N. (2007). Control of stress-dependent cardiac growth and gene expression by a microRNA. Science 316, 575-579. van Spronsen, M., van Battum, E.Y., Kuijpers, M., Vangoor, V.R., Rietman, M.L., Pothof, J., Gumy, L.F., van IJcken, W.F., Akhmanova, A., and Pasterkamp, R.J. (2013). Developmental and activity-dependent miRNA expression profiling in primary hippocampal neuron cultures. PLoS One 8, e74907.

Vo, N., Klein, M.E., Varlamova, O., Keller, D.M., Yamamoto, T., Goodman, R.H., and Impey, S. (2005). A cAMP-response element binding protein-induced microRNA regulates neuronal morphogenesis. Proc. Natl. Acad. Sci. USA 102, 16426-16431.

Wayman, G.A., Davare, M., Ando, H., Fortin, D., Varlamova, O. Cheng, H.-Y.M., Marks, D., Obrietan, K., Soderling, T.R., and Goodman, R.H. (2008). An activity-regulated microRNA controls dendritic plasticity by down-regulating p250GAP. Proc. Natl. Acad. Sci. USA 105, 9093-9098.

Wibrand, K., Panja, D., Tiron, A., Ofte, M.L., Skaftnesmo, K.O., Lee, C.S., Pena, J.T., Tuschl, T., and Bramham, C.R. (2010). Differential regulation of mature and precursor microRNA expression by NMDA and metabotropic glutamate receptor activation during LTP in the adult dentate gyrus in vivo. Eur. J. Neurosci. 31, 636645.

Xiong, X., Kang, X., Zheng, Y., Yue, S., and Zhu, S. (2013). Identification of loop nucleotide polymorphisms affecting microRNA processing and function. Mol. Cells 36, 518-526.

Yu, J.-Y. Chung, K.-H., Deo, M., Thompson, R.C., and Turner, D.L. (2008). MicroRNA miR-124 regulates neurite outgrowth during neuronal differentiation. Exp. Cell Res. 314, 2618-2633. 